\title{
Tourette's syndrome: from demonic possession and psychoanalysis to the discovery of genes
} Síndrome de Tourette: da possessão demoníaca e da psicanálise à descoberta dos genes Francisco M.B. Germiniani', Anna Paula P. Miranda², Peter Ferenczy³, Renato P. Munhoz ${ }^{4}$, Hélio A.G. Teive ${ }^{5}$

\begin{abstract}
In this paper we make a brief historical review of the hypothesis concerning the etiology of Tourette's syndrome (TS), focusing on varying trends over time: at first, its presumed relation to witchcraft and demonic possessions, followed by the psychoanalytical theory, which attributed TS to a masturbatory equivalent. Then, progressing to modern time, to the immunological theory and finally the advent of genetics and their role in the etiology of TS.
\end{abstract}

Key words: Tourette syndrome; tics; psychoanalysis; genes.

RESUMO

Os autores fazem uma breve revisão histórica enfatizando alguns importantes fatores relacionados com a síndrome de Tourette (ST) através dos tempos. Primeiramente, a relação da síndrome com possessões demoníacas, bruxaria; depois, a hipótese psicanalítica, que considerava os tiques como um equivalente masturbatório. Na sequência, discute-se a hipótese imunológica; depois, revisa-se a hipótese imunológica; finalmente, o papel dos genes na etiologia da ST.

Palavras-Chave: sindrome de Tourette; tiques; psicanálise; genes.

Tourette syndrome (TS) is a disease whose clinical manifestations are the occurrence of multiple motor tics and one or more vocal tics, lasting over one year, with onset of symptoms during childhood and often accompanied by additional symptoms: attention-deficit and hyperactivity disorder (ADHD) and obsessive-compulsive disorder $(\mathrm{OCD})^{1-3}$. The syndrome's name is a homage to French neurologist Georges Gilles de la Tourette, who, under the guidance of Professor Jean-Martin Charcot, made the first scientific report of the disease in 1885 , with a detailed description of nine patients, the first and most famous of which was the Marquise of Dampierre ${ }^{1,2}$.

TS has an estimated prevalence among children of $1 \%$. There's enough evidence to support a hyperdopaminergic state as the most likely physiopathogenic mechanism in TS, although the etiopathogeny remains unclear ${ }^{1,2}$.

We are making a brief historical account of TS, focusing on the medieval association of the disease with witchcraft and demonic possession, onwards to the psychoanalytical and immunological hypotheses, until the most recent genetic studies.

\section{WITCHES AND DEMONIC POSSESSION}

During the Middle Age, witch-hunting became widespread and resulted in a tool for systematic repression of feminism ${ }^{4}$. The basis for the creation of the famous book on identifying the practitioners of witchcraft, the Malleus Maleficarum (the Hammer of the Witches), published in 1486, was the belief that the Demon, trying to get hold of a person's soul, would posses his/her body, mostly through manipulation of sexual acts 5 .

Pope Inocencius VIII supported the publication of the Malleus Maleficarum (Fig 1) written by two Dominican monks ${ }^{5}$. In the book, they reported the case of a priest with no clear signs of cognitive dysfunction or eccentricities, which exhibited abnormal tongue movements, vocal tics and coprolalia whenever he kneeled in reverence of the Virgin Mary. He said that he couldn't prevent those behaviours from happening.

The priest's symptoms were attributed to an act of the Demon and he was "cured" by an act of Exorcism5. In the

\footnotetext{
Movement Disorders Unit, Neurology Service, Internal Medicine Department, Hospital de Clínicas, Universidade Federal do Paraná, Curitiba PR, Brazil: 'Neurologist and Intensivist; 


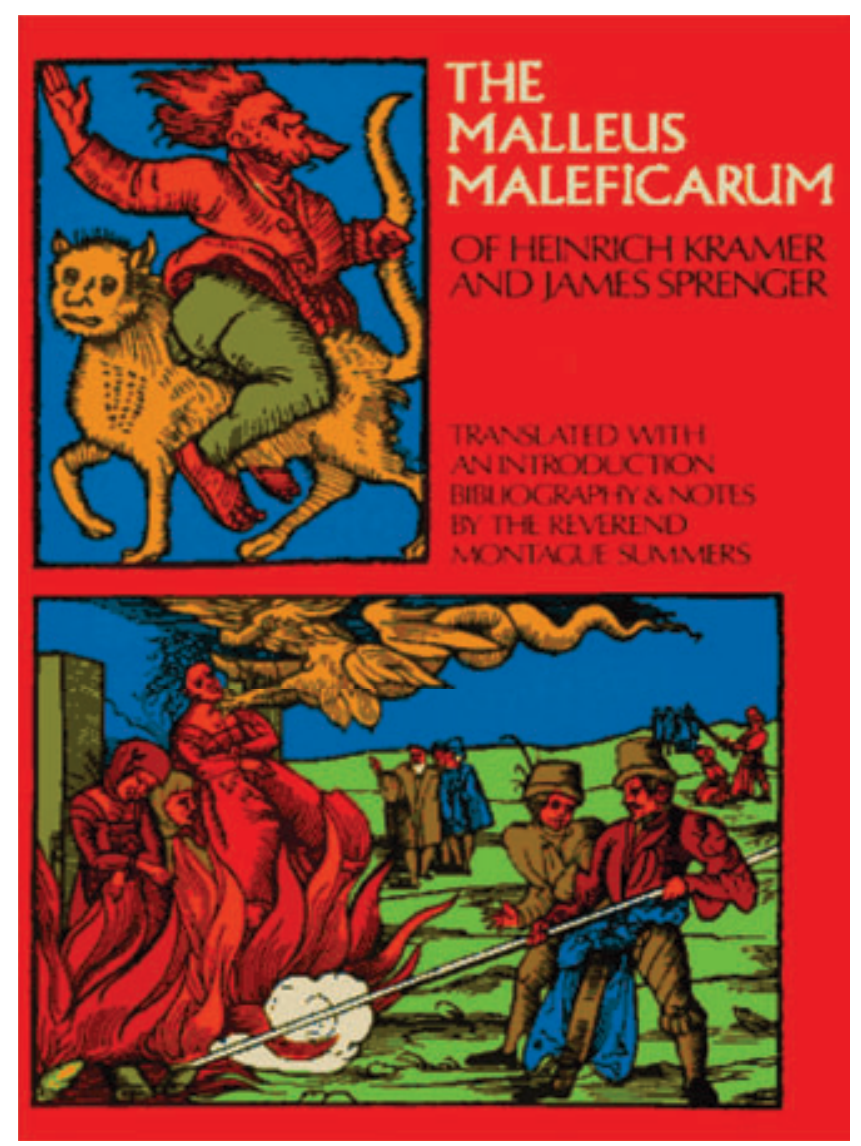

Fig 1. Malleus Maleficarum (the Hammer of the Witches). (D) Dover publications. Available at http://store. doverpublications.com/048.622.8029.html

same book, there's also the account of a woman who uttered obscenities compulsively during the mass, which could be interpreted as coprolalia at the exact moment that the priest gave the final blessing, the Dominus Oubiscum ${ }^{5}$. These should probably be the first written reports of persons with TS, whose symptoms were interpreted as signs of demonic possession, which resulted in them being targeted by the Inquisition and, not surprisingly, ending up in a fiery death at the stake ${ }^{4,5}$.

\section{“THE EXORCIST" - THE MOVIE}

In the famous book published by Shapiro in 1988, the authors argued that the ailment that afflicts the main character of the movie "The Exorcist" was most likely TS ${ }^{6}$. In the classic movie, the girl who had been "possessed by the Demon", superbly played by Linda Blair, presented with a variety of abnormal involuntary movements typical of motor and vocal tics. The character underwent an extensive evaluation at a neurological centre, and all exams were normal. A psychiatrist was consulted, but as there was no resolution from a medical standpoint, an exorcist priest was ultimately called upon to administer the definitive treatment ${ }^{6}$.

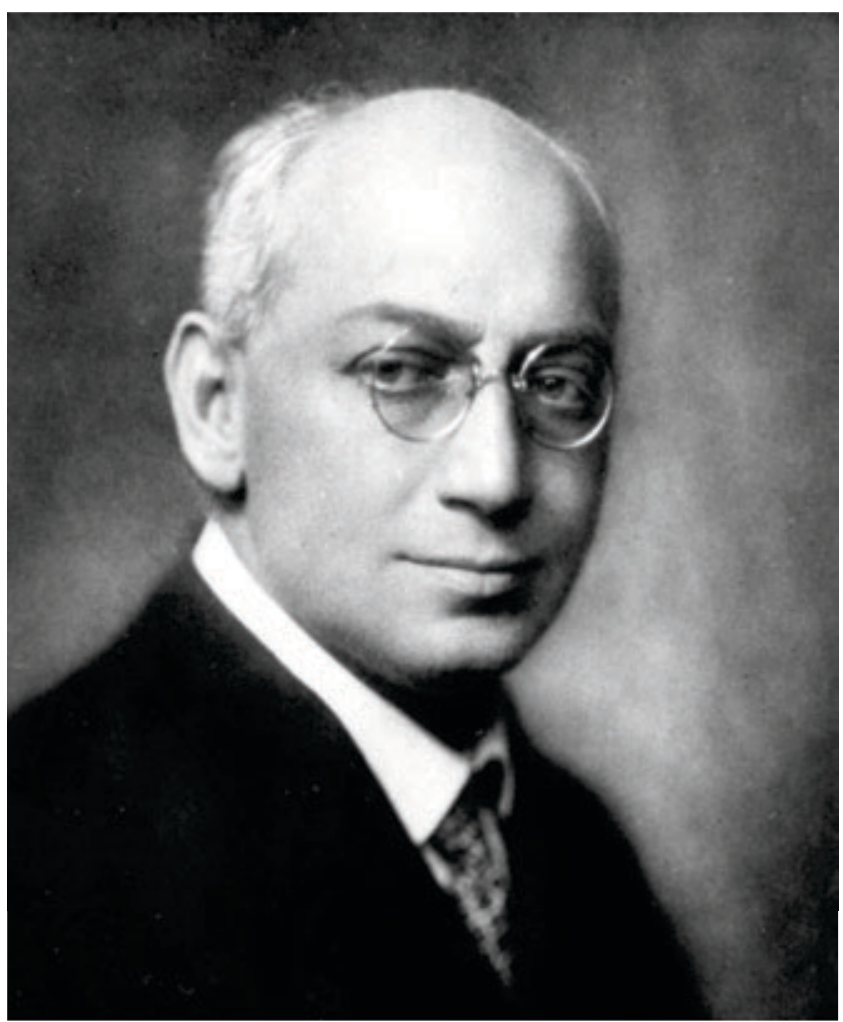

Fig 2. Sandor Ferenczi (1873-1933). Available at http:// en.wikipedia.org/wiki/File:FerencziS\%C3\%A1ndor.jpg

"The Exorcist", the movie, was supposedly based on the case of a young female patient who was admitted to Georgetown University in 1974 in order to investigate a bizarre ailment, which, in retrospect, was a possible case of $\mathrm{TS}^{6}$.

\section{THE PSYCHOANALYTICAL THEORY - FERENCZI'S MASTURBATORY EQUIVALENT}

Psychoanalyst Sandor Ferenczi (Fig 2), a disciple of Freud who worked in Budapest, was intrigued by tics, their florid presentation and the peculiar behaviours associated with them ${ }^{7}$. He wrote a few notes on tics as an appendix to his "Technical difficulties in the analysis of hysteria", in which he stated that tics could be equivalent to the act of masturbation remarking upon the connection between tics and coprolalia, which meant, in his opinion, a way of expressing the erotic feeling through vocalization ${ }^{7}$.

In an article published in 1921, "Psycho-analytical observations on tics", Ferenczi suggested that people afflicted with tics were both infantilized and narcissists, who lived under the rule of desire and couldn't withstand neither restrictions, nor being opposed7. In Ferenczi's words: "Tics may turn out to be stereotyped equivalents of Onanism...the remarkable connection of tics with coprolalia..." He also reported several other cases of patients with tics and their relation to onanism, such as "patient A - a tiqueur and an obstinate onanist". 


\section{THE IMMUNOLOGICAL HYPOTHESIS AND PANDAS}

In 1998, Swedo et al. ${ }^{8}$ proposed that children with either tics and/or OCD had an abrupt exacerbation of symptoms following an episode of streptococcal infection. This was dubbed as Pediatric Autoimmune Neuropsychiatric Disorders Associated with Streptococcal Infections (PANDAS) ${ }^{8}$. Ever since, several studies tried to prove this hypothesis, and a pathophysiological model was created to explain how a possible immunological effect could regulate dopaminergic circuitry leading to tics, but no definitive proof could be elicited. Nevertheless, no study has ever confirmed that a previous history of infection due to beta-hemolytic streptococci was associated with the onset or exacerbation of tics or OCD .

\section{THE GENETICAL HYPOTHESIS}

In the original description, Tourette himself remarked that this was a hereditary disorder ${ }^{1,2}$. A number of different hereditary studies have emerged and given support to this hypothesis ${ }^{10}$, such as linkage analysis of large kindreds, which has given evidence that TS might be genetically heterogeneous ${ }^{10}$. Furthermore, other reports suggest a complex mode of inheritance, with bilineal transmission (both maternal and paternal), and other studies have disclosed an association with some genetic loci affecting only a minority of persons. Finally, TS has been associated with genetic variations (deletions and duplications of specific DNA), with an abnormal increased number of repetitions of recurrent exonic copies, which can play a role in the pathogenesis of several neurodegenerative disorders ${ }^{10}$.

\section{FINAL REMARKS}

Over time, a disease that had been attributed to demonic possession and witchcraft, only to be later associated with masturbatory equivalents through psychoanalysis, has come a long way to the current understanding of its complex pathogenesis. The immunological hypothesis has been practically discarded, and there are high hopes that further neurogenetic research might bring some clues to the better understanding of TS.

\section{ACKNOWLEDGMENTS}

The authors would like to thank Dr. Plínio Lima for his kind support.

\section{References}

1. Kurlan R. Clinical practice. Tourette's syndrome. New Engl J Med 2010;363:2332-2338.

2. Teive HAG, Chien HF, Munhoz RP, Barbosa ER. Charcot's contribution to the study of Tourette's syndrome. Arq Neuropsiquiatr 2008; 66:918-921.

3. Tourette Syndrome Association International Consortium for Genetics. Genome scan for Tourette disorder in affected-sibling pair and multigenerational families. Am J Hum Genet 2007; 80:265-272.

4. Muraro RM. Introdução histórica. In: Kramer H, Sprenger J (editors). 0 Martelo das Feiticeiras (Malleus Maleficarum). $6^{\text {th }}$ ed. Rio de Janeiro: Rosa dos Tempos, 1991.

5. Kramer H, Sprenger J. Malleus maleficarum. Translated by reverend Montague Summers. London: Pushkin Press, 1948.
6. Shapiro AK, Shapiro ES, Young JG, Feinberg TE. Gilles de La Tourette Syndrome. $2^{\text {nd }}$ ed. New York: Raven Press, 1988.

7. Ferenczi S. Psycho-analytical observations on tic. IntJ Psychoanalysis 1921;2:1-30.

8. Swedo SE, Leonard HL, Garvey M, et al. Pediatric autoimmune neuropsychiatric disorders associated with streptococcal infections: clinical description of the first 50 cases. Am J Psychiatry 1998;155: 264-271.

9. Kurlan R, Johnson D, Kaplan EL, Tourette Syndrome Study Group. Streptococcal infection and exacerbations of childhood tics and obsessive-compulsive symptoms: a prospective blinded cohort study. Pediatrics 2008;121:1188-1197.

10. Sundaram SK, Huq AM, Wilson BJ, Chugani HT. Tourette syndrome is associated with recurrent exonic copy number variants. Neurology 2010;74:1583-1590. 